\title{
HLA Moleküllerinde Peptit Ligandlarının Kompleks Stabilitesine Olan Etkisinin Araştırılması
}

\author{
Investigation of the Effect of Peptide Binding on the Complex Stability \\ of HLA
}

\author{
Asuman BUNSUZ ${ }^{1}$ (i), Onur SERÇiNOĞLU ${ }^{1}$ (iD, Pemra ÖZBEK SARICA ${ }^{2}$ (D) \\ ${ }^{1}$ Marmara Üniversitesi, Fen Bilimleri Enstitüsü, Biyomühendislik Bölümü, 34722, İstanbul \\ ${ }^{2}$ Marmara Üniversitesi, Mühendislik Fakültesi, Biyomühendislik Bölümü, 34722, İstanbul
}

\begin{abstract}
$\ddot{O} z$
Hücre yüzey glikoproteinleri olan Temel Doku Uygunluk Kompleks (MHC) molekülleri yabancı antijenlere bağlanır ve onları uygun immün tanınma için antijen sunucu hücrelerin yüzeyindeki T lenfosit hücrelerine sunar. İlk olarak insanlarda lökosit hücrelerinde tanımlanmış oldukları için, aynı zamanda İnsan Lökosit Antijenleri (HLA) olarak da isimlendirilirler. Son zamanlarda peptit bazlı aşıların tasarlanması üzerine odaklanan çalışmalar, peptitin sitotoksik T hücre aracılı immün cevabı uyarma yeteneği olarak tanımlanan peptit immunojenite mekanizmasının anlaşılmasına olanak sağlamaktadır. Peptit immünojenisitesinin, peptit-HLA kompleksinin stabilitesi ile ilişkili olduğu bilinmektedir. Bu çalı̧̧mada, AIFQSSMTK and QVPLRPMTYK peptitlerini bağlayan HLA-A*03:01 ve HLA-A*11:01 alellerinin stabilitesinin temel moleküler mekanizmalarını ortaya çıkarmak için moleküler dinamik simülasyonları gerçekleştirilmiştir ve ENCOM sunucusu kullanılarak peptit rezidüleri üzerinde gerçekleş̧irilen tek nokta mutasyonlarının protein termostabilitesine olan tahmini etkisi araştırılmıştır.
\end{abstract}

Anahtar Kelimeler: MHC Molekülü, Stabilite, Moleküler Dinamik Simülasyonu, Mutasyon, ENCOM

\begin{abstract}
Major Histocompatibility Complex (MHC) genes encode for the MHC molecule which is a cell surface glycoprotein that binds to foreign antigens and presents them to T lymphocyte cells on the surface of Antigen Presenting Cells (APCs) for appropriate immune recognition. Initially they have been identified in human leukocyte cells; hence they are also referred to as Humans Leukocyte Antigens (HLAs) in humans. Recently, studies focusing on designing peptide-based vaccines have allowed a better understanding of the mechanism of peptide immunogenicity, which is defined as the ability of a peptide to stimulate CTL mediated immune response. Peptide immunogenicity is also known to be related to the stability of peptide-HLA complex. Although there are several experimental methods in literature, molecular dynamics (MD) simulation methods have been widely used to understand structural, kinetic and thermodynamics properties of peptide-MHC complexes at the atomic level. In this study, the molecular mechanisms underlying the stability of HLA-A*03:01 and HLA-A*11:01 alleles bound to AIFQSSMTK and QVPLRPMTYK peptides was investigated by performing 50 ns long MD simulations of these peptide-HLA complexes using NAMD 2.9 software with CHARMM22 force field at $310 \mathrm{~K}$. Root mean square deviation (RMSD), root mean square fluctuation (RMSF) and principal component (PCA) analysis were performed on the equilibrated MD simulation trajectories. According to RMSD analysis, in the presence of AIFQSSMTK peptide, HLA-A*03:01 allele is found to be more stable than HLA-A*11:01, while HLA-A*11:01 allele is found to be more stable than HLA-A*03:01 in the presence of QVPLRPMTYK peptide. Furthermore, according to PCA analysis, the differences between AIFQSSMTK peptide-HLA-A*03:01 and AIFQSSMTK peptide-HLA-A*11:01 complexes are observed in regions containing polymorphic residues (T9P, D90A, A152E, Q156L, E161D, P105S and R163T), while the differences between QVPLRPMTYK peptide-HLA-A*03:01 and QVPLRPMTYK
\end{abstract}


peptide-HLA-A*11:01 complexes are detected in regions containing polymorphic residues (D90A, A152E, Q156L, E161D ve R163T). Additionally, estimated effects of single point mutations on the protein thermostability were investigated via ENCOM server, which uses Modeller to create mutant models. Our computational mutagenesis studies reveal that for HLA-A*03:01 and HLA-A*11:01 alleles bound to AIFQSSMTK peptide; P2, P3 and $\mathrm{P} 9$ are the three strongest stabilizing residues whereas residue P10 is the most stabilizing residue for HLA-A*03:01 and HLA-A*11:01 alleles bound to QVPLRPMTYK peptide. Moreover, for AIFQSSMTK peptide, the importance of the secondary anchor residue, P6, on stable binding is recognized while for QVPLRPMTYK peptide, the importance of P7 on stable binding is observed. As a result, it can be concluded that the computational approaches used in this study provides detailed information for the stability of HLA-A*03:01 and HLA-A*11:01 alleles bound to AIFQSSMTK and QVPLRPMTYK peptides and our methodology can be used to guide future experiments in this field.

Keywords: MHC Molecules, Stability, Molecular Dynamics Simulations, Mutation, ENCOM

\section{GİRIŞ}

Omurgalılarda bulunan MHC (Major Histocompatibility Complex, Büyük Doku Uygunluk Kompleksi) sistemi insanlarda ilk kez lökosit hücrelerinde gözlemlenmiş olmalarından dolayı İnsan Lökosit Antijenleri-Human Leukocyte Antigen (HLA) olarak adlandırılmıştır ve bu adlandırma, insan MHC molekülleri için hali hazırda yaygınlıkla kullanılmaktadır. HLA antijenleri, 6. kromozomun kısa kolu üzerinde yerleşen MHC lokusu tarafindan kodlanmaktadır. HLA tarafından kodlanan proteinler kişiye özeldir ve bağ1şıklık sistemi tarafından kendinden olanı ve olmayanı ayırmakta kullanılır. Bu sayede hastalık tetikleyici yabancı proteinlere karşı savunma mekanizması oluşturur. Hücrelere yapışan yabancı proteinleri tanır, savunma hücreleri de onlara saldırır. Fizyolojik işlevleri, protein antijenlerinden kaynaklanan peptitleri antijene özgül $\mathrm{T}$ lenfositlerine sunmaktır. Organ nakillerinde HLA antijenlerinin uyumu son derece önemlidir, aksi takdirde bağışıklık sistemi tarafından diğer insanların doku antijenleri yabancı bir doku olarak algılanır ve reddetme tepkilerine yol açabilir. MHC lokusu bilinen en polimorfik gen bölgelerinden biridir ve $\mathrm{T}$ hücrelerine peptit sunan sinif I ve II MHC antijenlerini kodlar [1].

Her bir sınıf I molekülü bir $\alpha$ zinciri ve ona kovalent bağlı olmayan bağlarla bağlanan, $\beta 2$-mikroglobülin olarak adlandırılan ve MHC dışında kodlanan bir proteinden oluşur. Sınıf I molekülünün amino ucunun $\alpha 1$ ve $\alpha 2$ büklümleri 8-11 aminoasit uzunluğunda peptitlerin yerleşebileceği büyüklükte bir peptit bağlama oluğu oluşturur. Peptit bağlama oluğunun tabanı T lenfositlerine gösterilecek peptitlerin bağlandığı kısım, oluğun yanları ve üst kısmı ise T hücre reseptörü ile temas halinde bulunan kısımdır. Sınıf I moleküllerinin polimorfik rezidüleri, yani farklı bireylerin $\mathrm{MHC}$ molekülleri arasında farklılık gösteren aminoasitleri, $\alpha$ zincirinin $\alpha 1$ ve $\alpha 2$ alt birimlerinde yer alır. Zincirin $\alpha 3$ birimi değişken değildir ve T hücre eş-reseptörü CD8'in bağlanma noktasını içerir. Her sınıf II MHC molekülü bir $\alpha$ ve bir $\beta$ zincirinden oluşur. Her iki zincirin amino ucu, $\alpha 1$ ve $\beta 1$ alt birimleri, polimorfik rezidüleri içerir ve 10-30 aminoasit uzunluğunda peptitlerin yerleşebileceği büyüklükte bir peptit bağlama oluğu oluşturur. Değişken olmayan $\beta 2$ alt birimi T hücre eş-reseptörü CD4'ün bağlanma noktasını içerir $[1,2]$.

HLA kompleksleri üzerinde önceden yapılmış hesaplamalı çalışmalarda gruplar içerisinde benzer etkileşme mekanizmaları belirlenmiş, özellikle ligand bağlanma bölgelerinde alellelere özgü peptit tanıma ve bağlanma özellikleri görülmüştür [3 - 5]. Yapılan HLA-peptit bağlanma çalışmalarında dizi bazlı çalışmalardan dizi motifleri $[6,7]$, matris bazlı metotlar [8], yapay öğrenme ('machine learning') [911] ve destek vektör makineleri ('support vector machine', SVM) [10] gibi birçok hesapsal yöntem kullanılmıştır. Yap1 bazlı metotlar ise yüksek çözünürlüklü üç boyutlu yapıları kullanarak homoloji modelleme [12, 13], moleküler yanaşma ('docking') $[14,15]$ ve tarama ('threading') [16] metotlarını tek başına ya da bir arada kullanarak protein-peptit bağlanma tahmini yapmaktadır.

Bunların yanı sıra, bu zamana kadar, peptit-HLA etkileşimlerinin mekanizmasını anlamak için peptit bağlanma afinitesini ve HLA-peptit kompleksinin stabilitesini ölçen az sayıda çalışma yapılmıştır [17 - 20]. Bu çalışmalara ek olarak, deneysel çalışmalara yön göstermek ve sayısını azaltmak için peptit dizisine dayalı peptit bağlanma afinitesini ve HLA-peptit kompleksinin stabilitesini tahmin eden çeşitli hesaplamalı metotlar geliştirilmiştir [11, 21, 22, 23]. Fakat dizi temelli tahminler peptit bağlanma afinitesi ve HLA-peptit kompleksinin stabilitesinin doğru bir şekilde tahmin edilebilmesi için yeterli değildir. Bu sebeple, son yıllarda üç boyutlu yapıya dayalı tahminler gittikçe önemli hale gelmiştir ve peptit bazlı aşıların tasarlanması ile ilgili çalışmaların artmasıyla, peptitin sitotoksik T hücre aracılı immün cevabı uyarma yeteneği olarak tanımlanan peptit immunojenisite mekanizmasının anlaşılması konusu oldukça önem kazanmıştır [19, 22, 23, 24].

Literatürde çeşitli deneysel ve hesaplamalı metotlar olmasına rağmen, peptit-HLA komplekslerinin yapısal [25 - 29] kinetik [30] ve termodinamik [30, 31] özelliklerinin atomik düzeyde aydınlatılabilmesi için moleküler dinamik 
simülasyon metotları oldukça yaygın olarak kullanılmaktadır. Çünkü moleküler dinamik simülasyonları, protein stabilitesi için önemli olan molekül içi ve molekül dış1 güçler hakkında da en ayrıntılı bilgiyi vermektedir [31, 32]. Moleküler dinamik simülasyonları bu alanda daha sonra yapılacak olan deneysel çalışmalar için önfikir vermektedir.

Proteinde yer alan bazı rezidülerin mutasyonu protein yapısını ve termostabilitesini anlamlı bir şekilde etkileyebilmektedir [33]. Tek nokta mutasyonları ya da çoklu mutasyonlar denatürasyonun serbest enerjisini $(\Delta G)$ değiştirebilmekte ve $\Delta \mathrm{G}^{\prime}$ deki değişim $(\Delta \Delta \mathrm{G})$ de protein termostabilitesindeki değişiklikleri göstermektedir [34]. Mutasyonların termodinamik etkilerinin tahmini, hastalıklara neden olan mutasyonları anlamak için oldukça önemlidir. Bu çalışma kapsamında diğer çıktıları da desteklemek ve tamamlamak amacıyla Elastik Ağ Bağlantı Modeli (ENCOM) sunucusu kullanılmıştır. ENCOM proteinde var olan aminoasitlerin türünü ve etkileşen amino - asitlere özgü yan zincir etkileşimlerini hesap eden ilk normal mod analiz metodudur. ENCOM dinamikteki lokal farklılıkları tahmin edebilmekte ve termostabiliteyi titreşim entropisini temel alarak hesaplamaktadır [35].

(A3 süpertip ailesine ait olan HLA-A*0301 ve HLA-A*1101 alelleri bu ailenin en sik görülen allelleridir [36]. Yüksek derecede homolog olup benzer peptitleri çapraz olarak sunmaktadırlar [37]. Lichterfeld ve arkadaşları [38] insan bağışıklık yetmezlik virüsü (HIV) epitopları olan AIFQSSMTK ve QVPLRPMTYK peptitlerinin HLA-A*03:01 ve HLA-A*11:01 alellerine bağlandığını ve çapraz olarak $\mathrm{T}$ hücrelerine sunulduğunu ortaya çıkarmıştır. Son çalışmalarda [39], peptit bazlı HIV aşılarının geliştirilmesi için HLA-A*0301 ve HLA-A*1101 alellerinin AIFQSSMTK ve QVPLRPMTYK peptitlerini çapraz olarak nasıl sunduğunun mekanizması aydınlatılmaya çalışılmıştır.)

$\mathrm{Bu}$ çalışmada ise, insan bağ 1 şılık yetmezlik virüsü (HIV) epitopları olan AIFQSSMTK ve QVPLRPMTYK peptitlerini bağlayan HLA-A*03:01 ve HLA-A*11:01 alellerinin gerçek hareketleri moleküler dinamik simülasyon yöntemleri uygulanarak, olası hareketleri ise normal mod analizi uygulanarak incelenmiştir. Normal mod analizi için ENCOM sunucusu kullanılarak peptit rezidüleri üzerinde tek nokta mutasyonları gerçekleştirilmiş ve bu mutasyonlardan kaynaklanan tahmini protein termostabilite değişiklikleri $\Delta \Delta \mathrm{G}(\Delta \mathrm{kcal} / \mathrm{mol})$ değerleri olarak elde edilmiştir. Çalışmadan elde edilen sonuçların sonraki deneysel çalışmalar için yol gösterici olması beklenmektedir.

\section{MATERYAL VE YÖNTEM}

\subsection{Materyal}

$\mathrm{Bu}$ çalışma kapsamında, Protein Veri Bankasında (PDB) [40] üç boyutlu yapıları yayınlanmış olan AIFQSSMTK peptitini bağlayan HLA-A*03:01 (PDB Kodu: 3RL1 [39]) ve HLA-A*11:01 alelleri (PDB Kodu: 1Q94 [41]); QVPLRPMTYK peptitini bağlayan HLA-A*03:01 (PDB Kodu: 3RL2 [39]) ve HLA-A*11:01 alelleri (PDB Kodu: 1QVO [41]) klasik moleküler dinamik simülasyonları ve normal mod analizi için kullanılmıştır.

A3 süpertip ailesinin üyeleri olan A0303, A1101, A3101, A3301 ve Aw6801 alelleri benzer peptit bağlanma tercihleri gösteren sınıf I HLA molekülleridir. HLA-A3 alelleri, peptitlerinin 2. rezidü pozisyonunda genelde alanin (A), lösin (L), izolösin (I), valin (V), metiyonin (M), serin (S) ya da treonin (T) aminoasitlerini bulundururken karboksi ucunda ise pozitif yüklü aminoasitler olan arjinin (R) ve lizin $(\mathrm{K})$ aminoasitlerini bulundurmayı tercih ederler [39].

HLA-A*03:01 ve HLA-A*11:01 alelleri birbirlerinden peptit bağlanmasına ve $\mathrm{T}$ hücre reseptörü tanınmasına etki eden $\alpha 1$ ve $\alpha 2$ kısımlarında konumlanan 7 aminoasit sayesinde farklılaşmaktadır. Şekil 1'de polimorfik olan rezidüler proteinin üç boyutlu yapısı üzerinde gösterilmiştir. Bu 7 polimorfik rezidünün 2 tanesi $\alpha 1$ kısmında yer alan T9F ve D90A aminoasitleri iken, diğer 5 rezidü $\alpha 2$ kısmında bulunan P105S, A152E, Q156L, E161D ve R163T aminoasitleridir. 152, 161 ve 163. pozisyonlarındaki polimorfik rezidüler TCR bağlanma bölgesinde bulunduğu için HLA-A*03:01 ve HLA-A*11:01 alellerine bağlanan aynı peptitleri tanıyan farklı $\mathrm{T}$ hücre repertuarlarını anlayabilmek açısından önem arz etmektedir [39].

Bu çalışmada kullanılan AIFQSSMTK peptiti ters-transkriptaz enziminden elde edilen 9 aminoasitlik, QVPLRPMTYK peptiti ise Nef proteininden elde edilen 10 aminoasitlik insan bağışıklık yetmezlik virüsü (HIV) epitoplarıdır [41]. Peptitlerin farklı alellere bağlanma durumları Şekil 2'de detaylı olarak gösterilmiştir. 


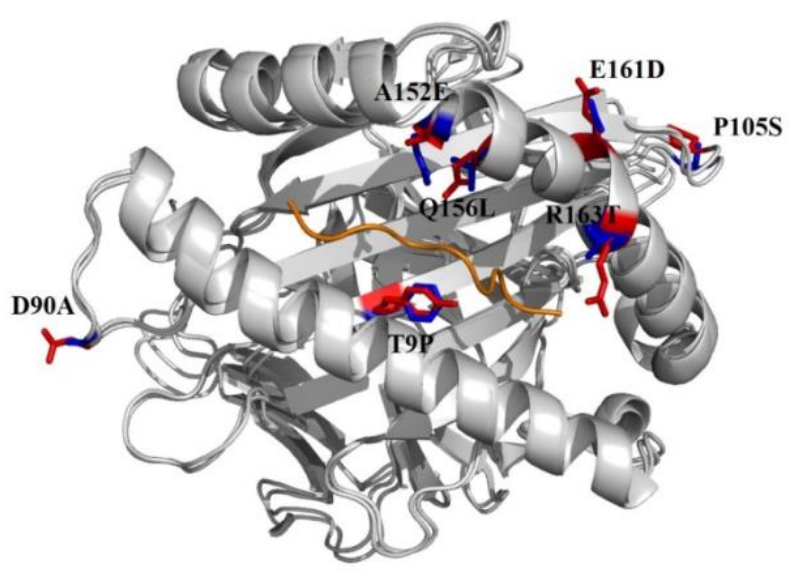

Şekil 1. AIFQSSMTK peptitini bağlayan HLA-A*03:01 (PDB ID : 3RL1 [39]) ve HLA-A*11:01(PDB ID : 1Q94 [41] ) alelleri arasında sekans diziliminin gösterimi, poli morfik rezidüler mavi (HLA-A*03:01) ve kırmızı (HLA-A*11:01) renkle işaretlenmiş, peptit turuncu renkle, molekül gri renkle gösterilmiştir.
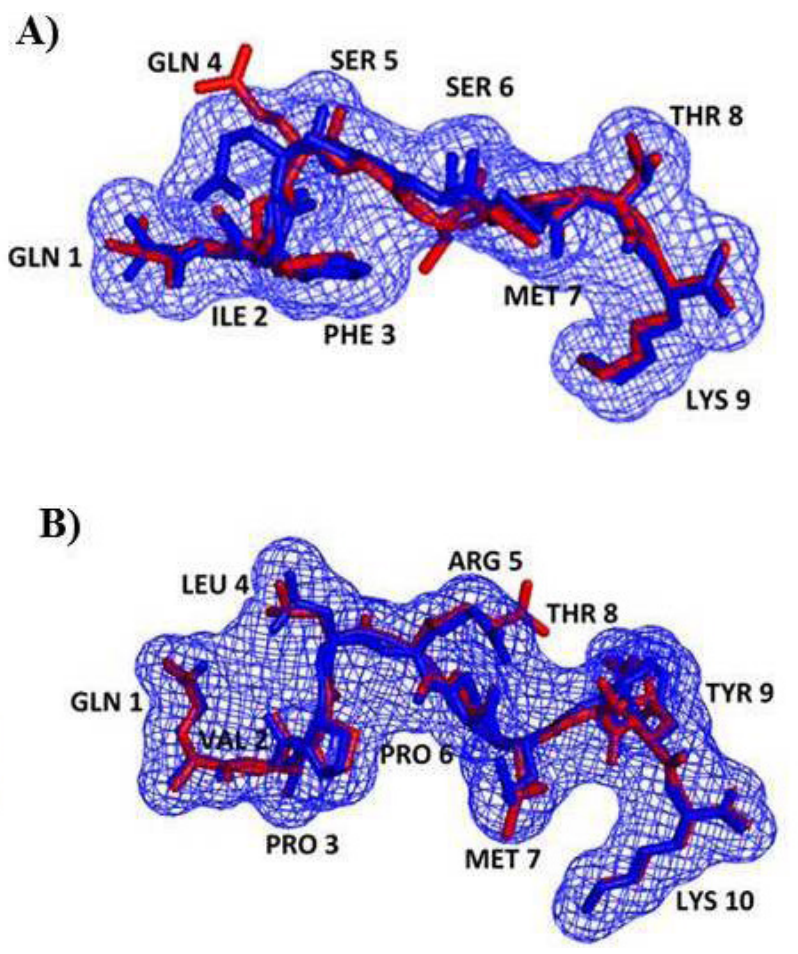

Şekil 2. (A) AIFQSSMTK peptitinin iki aleldeki konformasyonların üst üste konulmuş şekilde gösterimi,

HLA-A*03:01 mavi, HLA-A*11:01 kırmızı renk ile gösterilmiştir.

(B) QVPLRPMTYK peptitinin iki aleldeki konformasyonların üst üste konulmuş şekilde gösterimi, HLA-A*03:01 mavi,

HLA-A*11:01 kırmızı renk ile gösterilmiştir.

\subsection{Metot}

\subsubsection{Moleküler Dinamik Simülasyonları}

Biyolojik moleküllerdeki teorik çalışmalarda en temel araçlardan biri olan moleküler dinamik (MD) simülasyon metodu klasik Newton Mekaniği aracılığı ile sistemi modellerken moleküler sistemlerin zamana göre hareketlerini hesaplamakta etkin olarak kullanılmaktadır. Sistemin iyi temsil edilmesi, simülasyon sonuçlarını deney sonuçları ile uyumlu hale getirir.

$\mathrm{Bu}$ çalışma kapsamında, AIFQSSMTK ve QVPLRPMTYK peptitlerini bağlayan HLA-A*03:01 ve HLA-A*11:01 alelleri moleküler dinamik simülasyonları metodu uygulanmak üzere seçilmiş ve her iki molekül için 50 nanosaniye uzunluğunda ikişer adet MD simülasyonu yürütülmüştür. Simülasyon detayları Tablo 1'de verilmiştir.

Tablo 1. AIFQSSMTK ve QVPLRPMTYK peptitlerini bağlayan HLA-A*03:01 ve HLA-A*11:01 alelleri üzerinde yürütülen moleküler dinamik simülasyon detayları

\begin{tabular}{|c|c|c|c|c|c|}
\hline 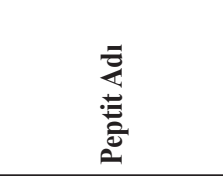 & $\begin{array}{l}\frac{\bar{z}}{2} \\
\frac{\mathrm{e}}{4}\end{array}$ & $\begin{array}{l}\text { 用 } \\
\text { 会 }\end{array}$ & 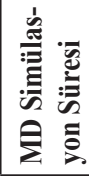 & 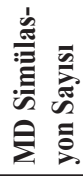 & 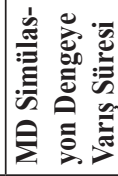 \\
\hline \multirow{2}{*}{ AIFQSSMTK } & HLA-A*03:01 & 3RL1 & $50 \mathrm{~ns}$ & 2 & $10 \mathrm{~ns}$ \\
\hline & HLA-A*11:01 & 1094 & $50 \mathrm{~ns}$ & 2 & $10 \mathrm{~ns}$ \\
\hline \multirow{2}{*}{ QVPLRPMTYK } & HLA-A*03:01 & 3RL2 & $50 \mathrm{~ns}$ & 2 & $10 \mathrm{~ns}$ \\
\hline & HLA-A*11:01 & 1QVO & $50 \mathrm{~ns}$ & 2 & $10 \mathrm{~ns}$ \\
\hline
\end{tabular}

MD simülasyonları su kutusunun boyutu $10 \AA^{3}$ olarak ve sıcaklık $310 \mathrm{~K}$ 'de NPT koşullarında, NAMD 2.9 Moleküler Dinamik [42] programı ve CHARMM22 [43] potansiyel fonksiyonu kullanılarak gerçekleştirilmiştir. Elde edilen konformasyonların analizi için ortalama kare kök sapma (RMSD), atomik koordinatların mobilite analizi için ortalama karekök dalgalanma (RMSF) ve aminoasit hareketlerindeki ortalama sapma değerlerinin üzerinde temel bileşenler analizi (Principal Component Analysis, PCA) hesapları yapılmışıtır. Bunlara ek olarak peptit RMSF analizleri de yapılarak peptit değişmezliği ve bağlanma stabilitesi kontrol edilmiştir.

Simülasyonların tamamlanmasının ardından, simülasyon gidişizinden belirlenecek denge kriteri olarak ortalama kare kök sapma (RMSD) sadece alfa karbonların koordinatları göz önünde bulundurularak hesaplanmıştır. Ortaya ç1kan grafiklere bakılarak tahmini dengeye ulaşma zamanları belirlenmiş ve takip eden analizlerde gidişizinin sadece bu zamandan sonraki konformasyonlarını içeren denge kısmı göz önünde bulundurulmuştur. Denge zamanının belirlenmesinden sonra, simülasyon gidişizlerinden su atomları 
silinmiş ve her bir simülasyon için sadece bağlanma bölgesinin (HLA zincirinin ilk 180 aminoasitini oluşturan $\alpha-1$ ve $\alpha-2$ bölgelerinin) polipeptit zincirinin omurgasını oluşturan atomlar (alfa karbon, amino grubu azot atomu ve karboksil grubu karbon atomu) temel alınarak konformasyonlar üst üste bindirilmiştir. Bu işlem için referans olarak üst üste bindirilecek tüm konformasyonları temsil eden ortalama bir konformasyon hesaplanmıştır. Daha sonra, her bir peptit aminoasidi için ortalama karekök dalgalanma (RMSF) değerleri hesaplanmıştır. Bu değer, her bir peptit pozisyonundaki aminoasidin bağlanma bölgesine göre olan ortalama mobilitesinin bir göstergesidir. Böylelikle, HLA molekülünün bağladığı peptitin proteinin dinamik karakterine nasıl etki gösterdiği görülebilir.

RMSF değeri, sadece peptit aminoasitlerinin değil, protein yapısındaki diğer aminoasitlerin de mobilitesinin bir göstergesi olarak kullanılabilir. Bu amaçla, yukarıdaki prosedüre benzer şekilde, tüm aminoasitlerin alfa-karbonları temel alınarak konformasyonlar üst üste bindirilmiş ve protein yapısındaki her bir aminoasit için RMSF değerleri hesaplanmıştır.

Protein üzerindeki dinamik iletişim ağını belirlemek üzere simülasyon dengeye ulaştıktan sonra, temel bileşenler analizi (Principal Component Analysis, PCA) yapılarak aminoasitlerin alfa karbon pozisyonlarının ortalamadan gösterdikleri sapmalar arasındaki çapraz korelasyon hesaplanmıştır. Bu çalışmada, toplam hareketin en yüksek özdeğerden başlayarak en az \%80'ini ifade eden bileşenlerden elde edilen alfa karbon çapraz korelasyon grafikleri elde edilmiştir. Aleller arası farklara bakıldığı gibi aynı alelin farklı peptitlere bağlanma durumundaki farklara da bakılmıştır.

\subsubsection{Peptit rezidüleri üzerinde uygulanan mutasyon analizi: ENCOM}

Mutasyonların termostabilite üzerindeki etkisini görebilmek için PDB yapıları, mutasyona uğratılacak rezidülerin pozisyon aralıkları, pozisyonların bulunduğu zincir ve gerçekleştirilmek istenen mutasyonlar girdi olarak kullanılara, tahmini $\Delta \Delta \mathrm{G}$ değerleri elde edilmiştir. Bu analiz kapsamında her mutant yapının konformasyonu Modeller [44] programı kullanılarak oluşturulmakta ve normal mod olarak oluşturulan konformasyonlar ana model olarak kullanılmaktadır. Protein yapısını ciddi bir şekilde bozan mutasyonlar için model oluşturulmamakta ve $\Delta \Delta \mathrm{G}$ sonuçları elde edilememektedir [45].

En doğru tahminlerin ENCOM ve FOLDX metotlarının lineer birleşmesiyle olduğunu ortaya koyan çalışmalar sonucunda; ENCOM sunucusu kullanıcılarına titreşimsel entropi temelli ENCOM ve entalpi temelli FOLDX metotlarıyla elde edilen tahmini $\Delta \Delta \mathrm{G}$ değerlerine ek olarak birleştirilmiş $\Delta \Delta \mathrm{G}$ değerleri de sunmaktadır [45].

$\mathrm{Bu}$ çalışmada QVPLRPMTYK ve AIFQSSMTK peptitlerinin her bir rezidüsü kendisi dışındaki diğer 19 rezidüye dönüştürülmüş ve $\Delta \Delta \mathrm{G}$ değerleri buna göre hesaplanmıştır. Peptit rezidüleri üzerinde gerçekleştirilen tek nokta mutasyonlarının termostabiliteye olan etkisi birleştirilmiş $\Delta \Delta \mathrm{G}$ değerleri dikkate alınarak incelenmiştir.

\section{BULGULAR ve TARTIŞMA}

\subsection{Peptit ve HLA molekülünün konformasyonel kararlılığı}

RMSD değerleri konformasyonel kararlılığın bir göstergesi olabilirler. HLA-A*03:01 ve HLA-A*11:01 alellerine mensup protein yapılarına uygulanan 50ns'lik simülasyon sonucu elde edilen RMSD-Zaman grafiği Şekil 3'de verilmiştir. Tüm simülasyonların 10. ns 'de dengeye geldiği gözlenmiş olup bundan sonra yapılması planlanan diğer analizler simülasyonun denge zamanından itibaren başlanarak uygulanmıştır.

Şekil 3'de ki RMSD-Zaman grafiğine göre, AIFQSSMTK peptitini bağlayan HLA-A*03:01 aleli en küçük RMSD değerlerini alırken, QVPLRPMTYK peptitini bağlayan HLA-A*03:01 aleli en yüksek RMSD değerlerini almıştır. Ayrıca bu grafikten, AIFQSSMTK peptitini bağlayan HLA-A*03:01 alelinin aynı peptidi bağlayan HLA-A*11:01 aleleine göre daha kararlı olduğu ve QVPLRPMTYK peptitini bağlayan HLA-A*11:01 alelinin ise aynı peptiti bağlayan HLA-A*03:01 aleline göre daha kararlı olduğu sonucu ortaya çıkmaktadır.

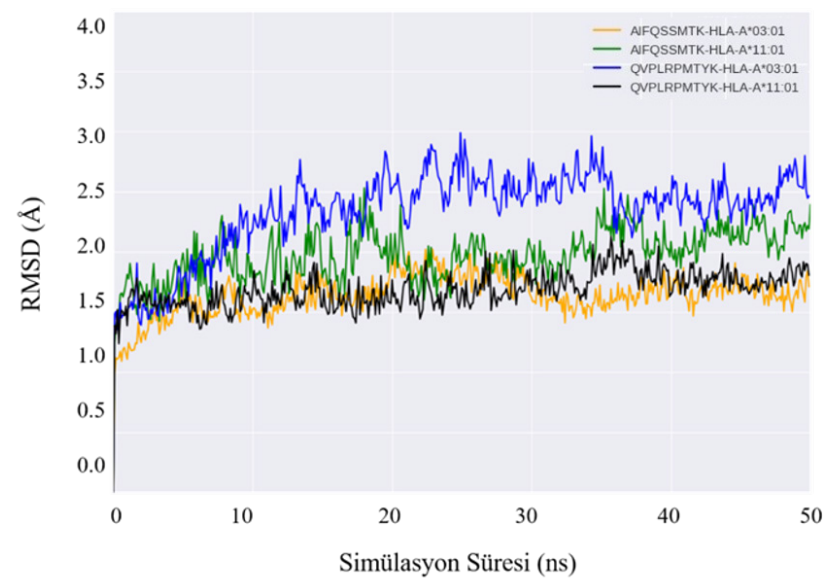

Şekil 3. AIFQSSMTK ve QVPLRPMTYK peptitlerine bağlanan HLA-A*03:01 ve HLA-A*11:01 alellerinin 50ns'lik MD simülasyonlarından elde edilen RMSD-Zaman grafiği 
A)

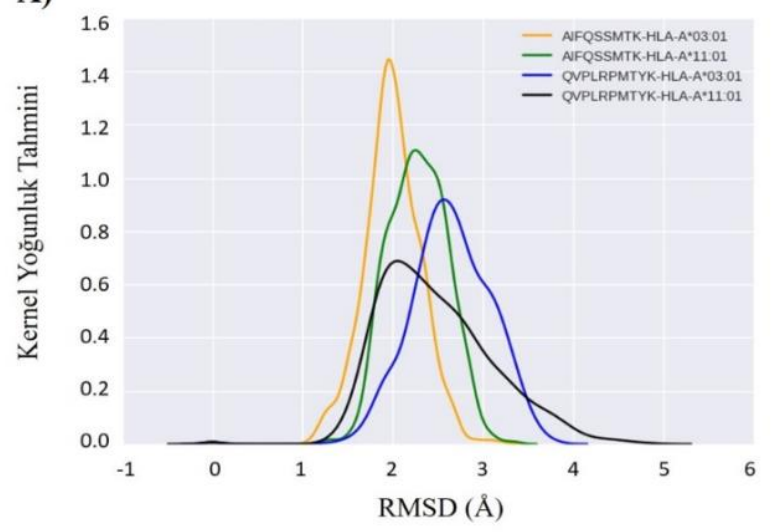

B)

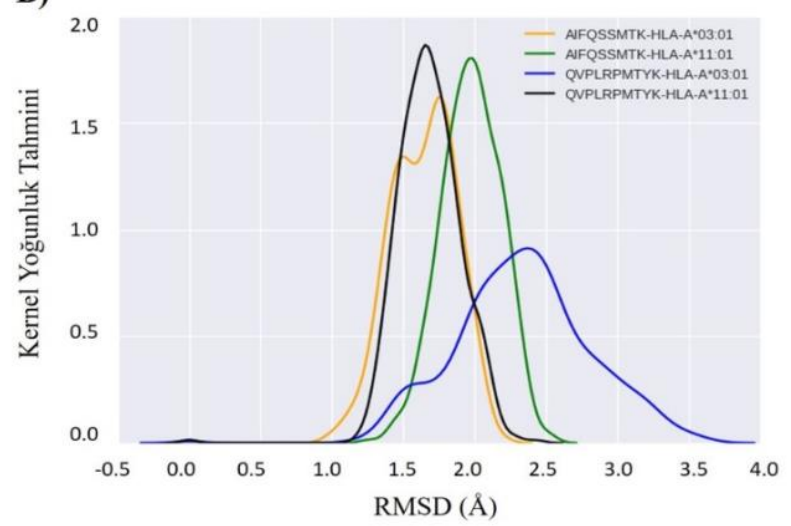

Şekil 4. (A) AIFQSSMTK ve QVPLRPMTYK peptitlerine bağlanan HLA-A*03:01 ve HLA-A*11:01 alellerinin 50ns'lik MD simülasyonlarından elde edilen RMSD dağılım grafikleri (B) AIFQSSMTK ve QVPLRPMTYK peptitlerine bağlanan HLA-A*03:01 ve HLA-A*11:01 alellerinin peptit bağlanma oluklarının 50ns'lik MD simülasyonlarından elde edilen RMSD dağılım grafikleri

RMSD-Zaman grafiklerine ek olarak, konformasyonel kararlılığı ölçmek için RMSD dağılım grafikleri de oluşturulabilir. RMSD dağılımının belirli bir değer etrafında kümelenmesi, proteinin konformasyonel açıdan daha kararlı olduğunu, dağılımın yayılması ile konformasyonel açıdan protein kararlılığının korunduğunu ifade eder.

Tüm protein ve bağlanma oluğu için RMSD dağılım değerleri ayrı ayrı hesaplanmış ve Şekil 4'te gösterilmiştir.

Tüm protein için elde edilen bulgulara göre, RMSD değerlerinde en yaygın dağılımın QVPLRPMTYK peptitini bağlayan HLA-A*11:01 alelinde, en dar dağılımın ise AIFQSSMTK peptitini bağlayan HLA-A*03:01 alelinde elde edildiği gözlemlenmiştir. Peptit bağlanma olukları için elde edilen bulgulara göre ise, RMSD değerlerinde en yaygın dağılımın QVPLRPMTYK peptitini bağlayan HLA-A*03:01 alelinde, en dar dağılımın AIFQSSMTK peptitini bağlayan HLA-A*03:01 alelinde elde edildiği gözlemlenmiştir. $\mathrm{Bu}$ sonuçlara göre, en kararlı sistemin AIFQSSMTK peptitini bağlayan HLA-A*03:01 aleli oduğu gözlemlenmektedir. Dağılım grafiklerinden elde edilen bu sonuçlar ile RMSD-Zaman grafiğinden elde edilen sonuçların aynı doğrultuda olduğu gözlenmektedir.

Sistemdeki konformasyonlar arasındaki farklılıkların bir göstergesi olan RMSD değerine ek olarak, protein polimerinin oluşturan yapı taşları olan aminoasitler seviyesinde de bilgi edinebilmek amacıyla her bir aminoasit için RMSF değerleri de hesaplanmıştır. Belirlenen denge kısmı için hesaplanan RMSF grafikleri, iki alel arasındaki farklılığ 1 oluşturan peptit bağlanma oluğunda konumlanan 7 polimorfik rezidünün (T9F, D90A, P105S, A152E, Q156L, E161D ve
R163T) genel protein dinamiğine etkisinin olmasından kaynaklanabilir ve beklenen bir sonuçtur. Belirli noktalarda görülen pikler hangi rezidülerin simülasyon süresince hareketli olduğu bilgisini vermektedir (Şekil 5 ve Şekil 6).

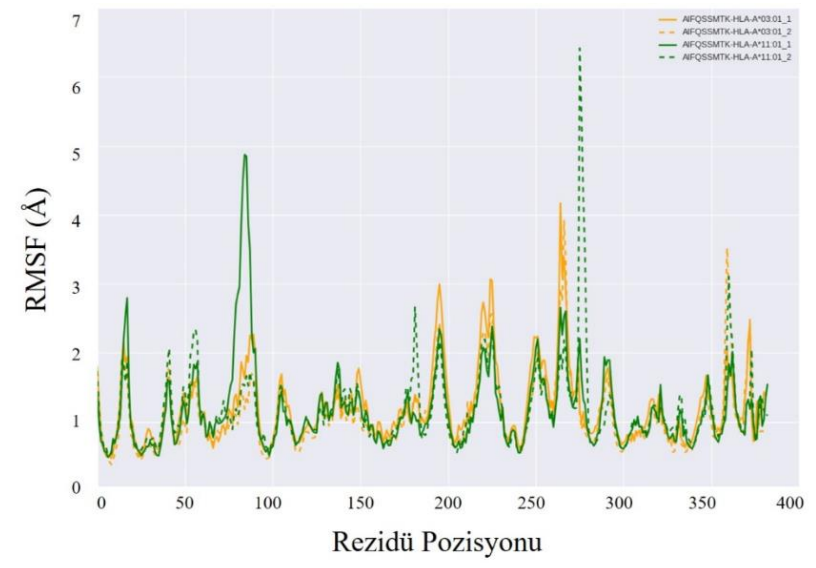

Şekil 5. AIFQSSMTK peptitine bağlanan HLA-A*03:01 ve HLA-A*11:01 alellerinin 50ns'lik MD simülasyonlarından elde edilen RMSF grafikleri

Genellikle tüm moleküller için aynı rezidülerde $(17,40$, 56, 84, 88, 89, 105, 181, 194, 220, 225, 251, 264, 275, 290, 359,372 ) hareketlilik görülmektedir. Bu rezidülerin yapı üzerindeki konumları incelendiğinde ilmek (loop) kısımlarını oluşturdukları gözlemlenmiştir. Bu kısımlar zaten hareket etmeye en müsait konumlar olduklarından bu noktalarda yüksek RMSF değerleri gözlemlenmesi beklenen bir sonuçtur. 


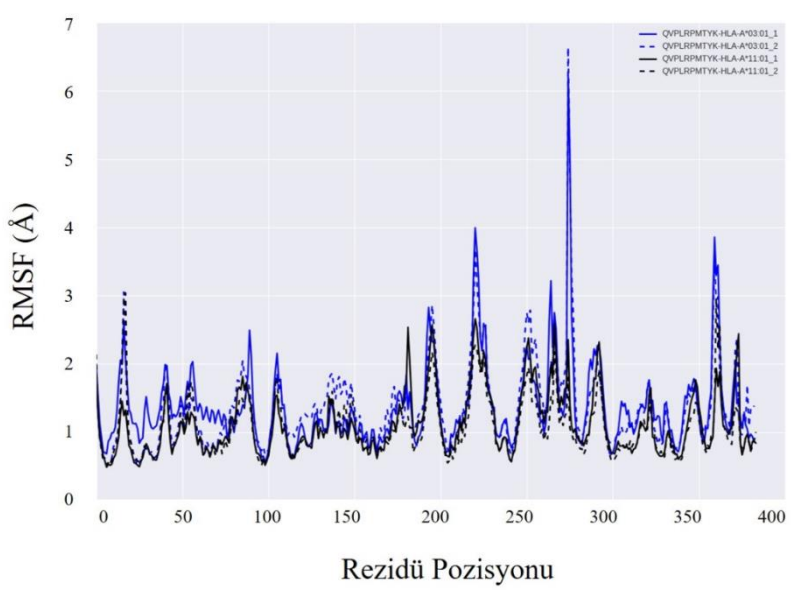

Şekil 6. QVPLRPMTYK peptitine bağlanan HLA-A*03:01 ve HLA-A*11:01 alellerinin 50ns'lik MD simülasyonlarından elde edilen RMSF grafikleri

Sadece peptit kısımlarının RMSF değerlerine bakılarak peptit stabilitesini anlamak mümkündür. 50 ns'lik simülasyonlar süresince peptit bağlanma oluğunda stabil konumdadır ve oluğun dışına çıkmadığı görülmektedir. Sonuçlar Şekil 7'de verilmiştir.

RMSF grafiklerinin genel profilleri, proteinin kararl1lığının aminoasit seviyesinde nasıl etkilendiğinin de (örn. proteindeki hangi bölgelerin mobilitesinde artış olduğunu) bir göstergesi olabilir. RMSF analizlerinden elde edilen sonuçlar ile AIFQSSMTK ve QVPLRPMTYK peptitlerine bağlanan HLA-A*03:01 ve HLA-A*11:01 alellerinin peptit bağlanma oluklarının 50ns'lik MD simülasyonlarından elde edilen RMSD dağılım grafiklerinin örtüştüğü görülmektedir. Bu sonuçlardan, AIFQSSMTK peptitini bağlayan HLA-A*03:01 alelinin aynı peptiti bağlayan HLA-A*11:01 aleline göre daha stabil olduğu, QVPLRPMTYK peptitini bağlayan HLA-A*11:01 alelinin ise HLA-A*03:01 aleline göre daha stabil olduğu ortaya çıkmaktadır. Yüksek RMSF değerleri, beklenilebileceği üzere, peptit ile bağlantı kuran bağlanma oluğu aminoasitlerinin hemen hemen tamamında, $\alpha 3$ ve $\beta 2$-mikroglobülin'de ise sadece ilmek kısımlarında gözlemlenmiştir.

Bağlanma oluğu RMSD değerleri incelendiğinde, AIFQSSMTK peptitini bağlayan HLA-A*11:01 alellerinin ve QVPLRPMTYK peptitini bağlayan HLA-A*03:01 alellerinin yaygın dağılım gösterdikleri görülmektedir. Peptit RMSF değerleri de incelediğinde, HLA-A*11:01 aleline bağlı olan AIFQSSMTK peptitinin HLA-A*03:01 aleline bağlanan aynı peptite göre daha az stabil durumda olduğu, HLA-A*03:01 aleline bağlı olan QVPLRPMTYK peptitin ise HLA-A*11:01 aleline bağl1 olan aynı peptite göre da az stabil durumda olduğu görülmektedir ve bu sonuçlar bağlanma oluğu RMSD değerleri ile örtüşmektedir.

RMSF analizlerinden elde edilen sonuçlara göre, AIFQSSMTK peptitini bağlayan HLA-A*03:01 ve HLA-A*11:01 alellerinin mobilitelerinin D90A' nın konumlandığı bölgede belirgin bir şekilde farklılık gösterdiği görülmektedir. 90. rezidünün polimorfik rezidü olması ve bu polimorfizmden kaynaklanan farkl111klar AIFQSSMTK peptitini bağlayan HLA-A*03:01 alelinin HLA-A*11:01 aleline göre daha stabil olmasina sebep olabilir.
A)

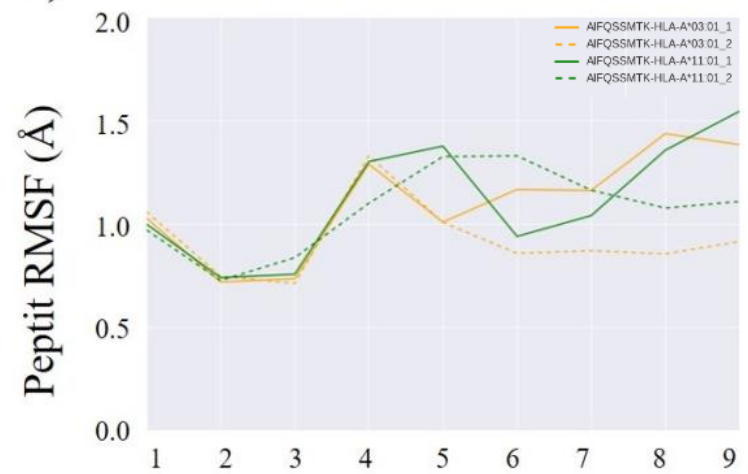

B)

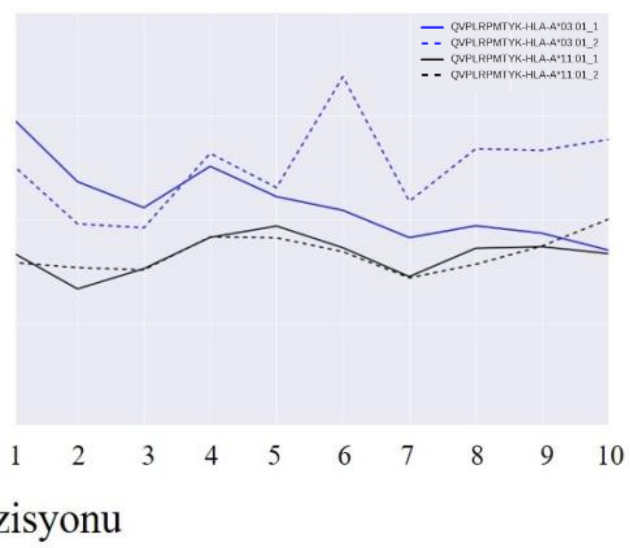

Şekil 7. (A) AIFQSSMTK peptitini bağlayan HLA-A*03:01 ve HLA-A*11:01 alellerinin 50ns'lik MD simülasyonlarından elde edilen peptit RMSF grafikleri (B) QVPLRPMTYK peptitini bağlayan HLA-A*03:01 ve HLA-A*11:01 alellerinin 50ns'lik MD simülasyonlarından elde edilen peptit RMSF grafikleri 
Grafiklere bakıldığında, AIFQSSMTK peptitini bağlayan HLA-A*11:01 alellerinin mobilitelerinin 275. rezidünün bulunduğu k1sımlarda HLA-A*03:01 alellerine göre daha fazla olduğu, QVPLRPMTYK peptitini bağlayan HLA-A*03:01 alellerinin mobilitelerinin ise aynı rezidünün bulunduğu kısımlarda HLA-A*03:01 alellerine göre daha fazla olduğu gözlemlenmiştir. Bu kısım hareket etmeye en müsait konum olan ilmek bölgesinde olduğundan bu noktada yüksek RMSF değerleri gözlemlenmesi beklenebilir.

HLA-A*03:01 alelinde AIFQSSMTK peptiti bağliyken polimorfik rezidü olan E152 peptit bağlanma oluğunun içine doğru yöneldiği için peptitin bağlanma alanı sınırlanmıştır, buna karşın HLA-A*03:01 aleli QVPLRPMTYK peptitine bağlıyken bağlanma oluğundan dişarıya yönelerek peptitin alele bağlanması için daha geniş bir alan oluşturmaktadir [39]. Bu sebeple, RMSF analizlerinde QVPLRPMTYK peptitine bağl1 olan HLA-A*03:01 alelinin, AIFQSSMTK peptitine bağlı olan HLA-A*03:01 aleline kıyasla daha hareketli olduğu görülmektedir ve bu sonuçlar literatürde bulunmuş olan veriler ile örtüşmektedir [39].

HLA-A*11:01 alelinde AIFQSSMTK peptiti bağliyken polimorfik rezidü olan A152 alanin aminoasitinin küçüklüğü nedeniyle peptitin 6 . rezidüsünün yan zincirleri peptit bağlanma oluğuna rahatça yerleşmektedir, fakat HLA-A*03:01 alelinde E152 geniş glutamin aminoasiti olduğu için peptitin 6. rezidüsü yan zincirlerini peptit bağlanma oluğuna yerleştirirken sınırlanmaktadır [39]. 152. rezidüde görülen bu farklılık sonucunda, RMSF analizlerinde AIFQSSMTK peptitine bağl1 olan HLA-A*03:01 alelinin, AIFQSSMTK peptitine bağlı olan HLA-A*11:01 aleline kıyasla daha az hareketli olduğu görülmektedir ve bu beklenen bir sonuçtur.

HLA-A*03:01 alelinde QVPLRPMTYK peptiti bağlyyken polimorfik rezidü olan E152 ile peptitin 5. rezidüsünün tuz köprüsü oluşturmakta, buna karş1 HLA-A*11:01 alelinde A152 rezidüsü böyle bir bağ yapmamaktadır. Ayrica, HLA-A*11:01 alelinde peptitin 5. pozisyondaki arjinin aminoasitinin yan zincirleri peptite doğru yönelerek peptitin hareketliliğine sınırlayıcı etkide bulunmaktadır [39]. Bu sebeple, RMSF analizlerinde QVPLRPMTYK peptitine bağl1 olan HLA-A*03:01 alelinin, QVPLRPMTYK peptitine bağl1 olan HLA-A*11:01 aleline k1yasla daha hareketli olduğu görülmektedir ve bu sonuçların literatürde bulunmuş olan veriler ile uyumlu olduğu anlaşılmaktadır [39].

Temel Bileşen Analizi’nden elde edilen sonuçlar paralel simülasyonlar için oldukça benzer çıkmaktadır. Bu sebeple her paralel simülasyonu temsilen sadece bir grafik konulmuştur (Şekil 8). Temel Bileşen Analizi'nden elde edilen sonuçlara bakıldığında aynı peptite bağlanan farklı alellerin durumu karşılaştırılmıştır. Bu farklılıklar siyah noktalı daireler içine alınarak vurgulanmıştır. AIFQSSMTK peptitini bağlayan HLA-A*03:01 ve HLA-A*11:01 alelleri arasında tespit edilen farklılıkların peptit bağlanma oluğunda konumlanan T9P, D90A, A152E, Q156L, E161D, P105S ve R163T polimorfik rezidülerinin olduğu bölgelerde yoğunlaştığ1 görülmektedir. QVPLRPMTYK peptitini bağlayan HLA-A*03:01 ve HLA-A*11:01 alelleri arasinda tespit edilen farklılıkların ise peptit bağlanma oluğunda konumlanan D90A, A152E, Q156L, E161D ve R163T polimorfik rezidülerinin olduğu bölgelerde yoğunlaştığı görülmektedir.

AIFQSSMTK peptitini bağlayan HLA-A*03:01 alelinin T73 rezidüsü peptitin 6 . rezidüsü ile hidrojen bağ 1 oluşturmakta, buna karşın HLA-A*11:01 alelinde R114 rezidüsü peptitin 6. rezidüsü ile hidrojen bağı oluşturmaktadır [39]. Dolayısıyla, AIFQSSMTK peptitini bağlayan aleller arası tespit edilen farklılığın 73. rezidünün konumlandığı bölgeye de yansıdığı gözlemlenmektedir. Bu sonuca göre, 73. rezidünün AIFQSSMTK peptitini bağlayan HLA-A*03:01 alelinin stabilitesini artırdığ 1 söylenebilir. HLA-A*11:01 alelinin bağlanma olduğu RMSF değerlerine bakıldığında, 73 . rezidünün bulunduğu bölgenin mobilite değerlerinde artış, bu bulguyu desteklemektedir (Şekil 5).

Ayrıca, AIFQSSMTK peptitini bağlayan aleller arası tespit edilen farklılığın D90A polimorfik rezidüsünün konumlandığ1 bölgeye de yansıdığı gözlemlenmektedir. RMSF analizleri de, 90. rezidünün bulunduğu bölgenin mobilite değerlerinin HLA-A*11:01 alelinde artış gösterdiğini ortaya çıkardığı için polimorfik rezidü D90A' nın AIFQSSMTK peptitini bağlayan HLA-A*03:01 alelinin stabilitesini artırmada önemli rol oynadığı söylenebilir (Şekil 5).

HLA-A*03:01 alelinde QVPLRPMTYK peptiti bağliyken polimorfik rezidü olan E152, peptitin 5. rezidüsü ile tuz köprüsü oluşturmakta, fakat HLA-A*11:01 alelinde ise A152 rezidüsü peptit ile bağ kurmamaktadır [39]. Bu sebeple, QVPLRPMTYK peptitini bağlayan aleller arası tespit edilen farklılığın 152. rezidünün konumlandığı bölgeye yansıdığı gözlemlenmektedir. Bu sonuca göre, 152. rezidünün değişmesinin QVPLRPMTYK peptitini bağlayan aleller arasındaki stabilite farkına etkisinin olduğu söylenebilir.

HLA-A*03:01 alelinde AIFQSSMTK peptiti bağliyken polimorfik rezidü olan E152' nin peptit bağlanma oluğunun içine doğru yönelmesi, buna karşın HLA-A*03:01 aleli QVPLRPMTYK peptitine bağliyken bağlanma oluğundan dışarıya yönelmesi HLA-A*03:01 alelleri arası tespit edilen farklılığın 152. rezidünün konumlandığı bölgeye yansımasına neden olabilmektedir. Polimorfik olan 152. rezidü, AIFQSSMTK peptitini bağlayan HLA-A*03:01 alelinin QVPLRPMTYK peptitini bağlayan HLA-A*03:01 aleline göre daha stabil yapıda olmasına sebep olabilir. 


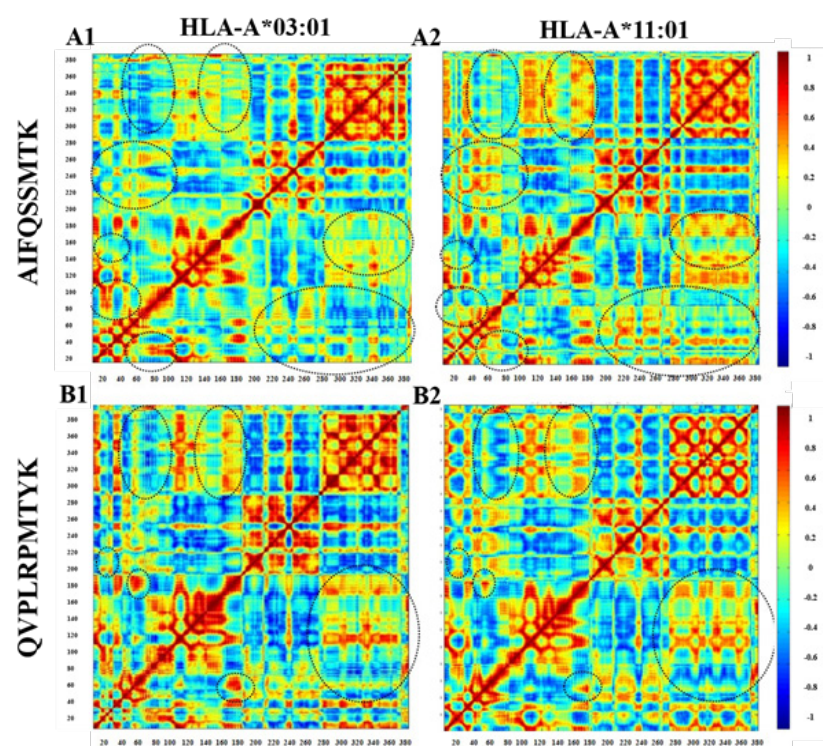

Şekil 8. MD simülasyonlarının denge kısmında alfa karbonların ortalamadan gösterdikleri sapmaya uygulanan PCA analizinden elde edilen temel bileşenlerin toplam varyansın en az \%80'ini ifade edenlerinden elde edilen çapraz korelasyon grafikleri. (A1) AIFQSSMTK peptitini bağlayan HLA-A*03:01 aleli (A2) AIFQSSMTK peptitini bağlayan HLA-A*11:01 aleli (B1) QVPLRPMTYK peptitini bağlayan HLA-A*03:01 aleli (B2) QVPLRPMTYK peptitini bağlayan HLA-A*11:01 aleli. Proteinin HLA zinciri (1-274. (HLA-A*03:01) ve 1-275. (HLA-A*11:01) rezidüler aras1), $\beta 2$-mikroglobulin zinciri (275-374. (HLA-A*03:01) ve 276-375. (HLA-A*11:01) rezidüler aras1) ve peptit zinciri (375-383. (HLA-A*03:01/ AIFQSSMTK) - 375-384. (HLA-A*03:01/ QVPLRPMTYK) ve 376-384. (HLA-A*11:01/AIFQSSMTK)-377-385. (HLA-A*11:01/ QVPLRPMTYK) rezidüler arası)

ENCOM sunucusu kullanılarak peptit rezidüleri için bir rezidünün kendisi dışındaki diğer 19 rezidüye dönüştürülmesi sonucu elde edilen tek nokta mutasyonlarının termostabiliteye olan etkisi birleştirilmiş $\Delta \Delta \mathrm{G}$ değerleri dikkate alınarak incelenmiş̧ir (Şekil 9). 4 farklı kompleksin peptitleri için hangi peptit rezidülerinin protein termostabilitesinde önemli rol oynadığı tespit edilmiştir. Mutasyonların tahmin edilen $\Delta \Delta \mathrm{G}$ değerlerini gösteren isı haritalarının renk gradyan1; protein termostabilitesini artıran mutasyonlar için mavi renkle, protein termostabilitesini azaltan mutasyonlar için ise kırmızı renkle orantılı olarak ayarlanmıştır. Buna göre bir mutasyonun tahmin edilen $\Delta \Delta \mathrm{G}$ değerinin mavi renkte olması, bu mutasyonun protein yapısının stabilitesini artırdığı için tercih edilebilir olduğu; kırmızı renkte olması ise mutasyonun yapının stabilitesini azalttığı için tercih edilmediği anlamına gelmektedir. Bununla birlikte, protein yapısını ciddi bir şekilde bozan mutasyonlar için model oluşturulmamakta ve $\Delta \Delta \mathrm{G}$ sonuçları elde edilememektedir
[34]. Bu nedenle 1si haritalarinda modellenemeyen ve $\Delta \Delta \mathrm{G}$ değeri ölçülemeyen yapılar beyaz renkte gösterilmektedir.

AIFQSSMTK peptitini bağlayan HLA-A*03:01 (3RL1) ve HLA-A*11:01 (1Q94) yapıları için peptitin 2., 3. ve 9. rezidüleri üzerinde gerçekleş̧irilen tek nokta mutasyonlarının; QVPLRPMTYK peptitini bağlayan HLA-A*03:01 (3RL2) ve HLA-A*11:01 (1QVO) yapıları için ise peptitin 10. rezidüsü üzerinde gerçekleştirilen tek nokta mutasyonlarının protein termostabilitesini önemli ölçüde azalttığı gözlemlenmektedir. Normal mod analizinden elde edilen veriler, HLA-A3 alellerinin peptitlerinin 2. rezidü pozisyonunda genelde alanin (A), lösin (L), izolösin (I), valin (V), metiyonin (M), serin $(\mathrm{S})$ ya da treonin $(\mathrm{T})$ aminoasitlerini, karboksi ucunda ise pozitif yüklü aminoasitler olan arjinin (R) ve lizin (K) aminoasitlerini bulundurmayı tercih ettiğini ortaya koyan deneysel veriler [39] ile örtüşmektedir.

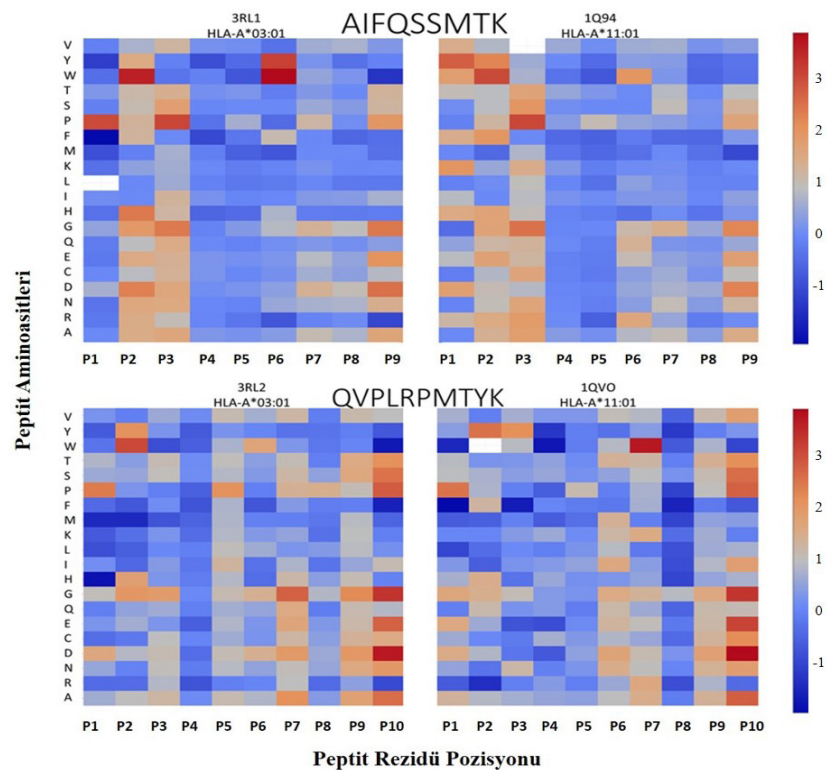

Şekil 9. AIFQSSMTK ve QVPLRPMTYK sekanslarına sahip peptitler üzerinde gerçekleştirilen tek nokta mutasyonlarının protein termostabilitesine olan etkileri

Bunlara ek olarak, AIFQSSMTK peptitinin ikincil derecede önemli olan 6. rezidüsünün ve QVPLRPMTYK peptitinin ikincil derecede önemli olan 7. rezidüsünün protein termostabilitesindeki önemi isı haritalarında da gözlemlenmektedir [41]. Öte yandan, her iki peptit üzerinde gerçekleştirilen mutasyonların her peptit pozisyonunda aynı seviyede etkiye sahip olmadığı da gözlemlenmektedir. Özellikle 2. ve 3. rezidülerde AIFQSSMTK peptitinde yapılan mutasyonların, QVPLRPMTYK peptitinin aynı pozisyonlarında yapılan mutasyonlara göre protein termostabilitesine daha negatif bir etkisinin olduğu söylenebilir. Buna ek olarak, 
QVPLRPMTYK peptiti için peptit bağlanmasında biricil derecede önemli olan 2. pozisyonda ki rezidünün ve karboksi ucunda bulunan rezidünün protein termostabilitesine eşit derecede etkisinin olmadığı sonucu da çıkarılabilir.

\section{SONUÇ}

$\mathrm{Bu}$ çalışmada, insan bağışıklık yetmezlik virüsü (HIV) epitopları olan AIFQSSMTK ve QVPLRPMTYK peptitlerine bağlanan HLA-A*03:01 ve HLA-A*11:01 alelleri arasındaki farklılığı oluşturan peptit bağlanma oluğunda konumlanan 7 polimorfik rezidünün (T9F, D90A, P105S, A152E, Q156L, E161D ve R163T) 4 farklı peptit-HLA kompleksinin peptit bağlanma mekanizmalarını nasıl farklılaştırdığı incelenmiştir. AIFQSSMTK peptiti 2. rezidü pozisyonunda izolösin (I) aminoasitini 9. rezidü pozisyonunda ise lizin (K) aminoasitini bulundurduğu için, QVPLRPMTYK peptiti de 2. rezidü pozisyonunda valin (V) aminoasitini 9. rezidü pozisyonunda ise lizin (K) aminoasitini bulundurduğu için HLA-A*03:01 ve HLA-A*11:01 alellerine bağlanarak stabil yapılar oluşturmaktadır [39]. Fakat, HLA-A*03:01 ve HLA-A*11:01 alelleri arasındaki farklılığı oluşturan peptit bağlanma oluğunda konumlanan 7 polimorfik rezidü (T9F, D90A, P105S, A152E, Q156L, E161D ve R163T) peptit-HLA komplekslerinin peptit bağlanma mekanizmalarını farklılaştırdığı [39] için protein stabilitelerinin farklılaşmasına sebep olmaktadır. Bu çalışma kapsamında gerçekleştirilen moleküler dinamik simülasyonları AIFQSSMTK peptitini bağlayan HLA-A*03:01 alelinin aynı peptiti bağlayan HLA-A*11:01 aleline göre daha stabil olduğunu, QVPLRPMTYK peptitini bağlayan HLA-A*11:01 alelinin ise aynı peptiti bağlayan HLA-A*03:01 aleline göre daha stabil olduğunu ortaya çıkarmıştır (Şekil 4 ve Şekil 5). Temel bileşen analizlerinden elde edilen sonuçlar, AIFQSSMTK peptitini bağlayan HLA-A*03:01 ve HLA-A*11:01 alelleri arasında tespit edilen farklılıkların peptit bağlanma oluğunda konumlanan T9P, D90A, A152E, Q156L, E161D, P105S ve R163T polimorfik rezidülerinin olduğu bölgelerde yoğunlaştığını, QVPLRPMTYK peptitini bağlayan HLA-A*03:01 ve HLA-A*11:01 alelleri arasinda tespit edilen farklılıkların ise peptit bağlanma oluğunda konumlanan D90A, A152E, Q156L, E161D ve R163T polimorfik rezidülerinin olduğu bölgelerde yoğunlaştığını göstermektedir (Şekil 8). Literatürdeki çalışmalar, HLA-A*03:01 ve HLA-A*11:01 alelleri arasındaki farklılığı oluşturan polimorfik rezidü A152E nin peptit konformasyonu üzerinde önemli etkisinin olduğu göstermiştir [39]. Bu çalışma kapsamında yapılan temel bileşen analizleri, 152. rezidünün AIFQSSMTK peptitini bağlayan HLA-A*03:01 alelinin aynı peptiti bağlayan HLA-A*11:01 aleline göre daha stabil olmasında büyük etkisinin olduğunu göstermektedir. Buna karşın, 152. rezidünün QVPLRPMTYK peptitini bağlayan HLA-A*11:01 alelinin HLA-A*03:01 aleline göre daha stabil olmasinda önemli rol oynadığı görülmektedir (Şekil 8). Çalışma kapsamında elde edilen sonuçlar, protein stabilitesinin 152. rezidünün peptit konformasyonununu etkilemesi sonucu her iki peptitin de HLA-A*03:01 ve HLA-A*11:01 alelleri ile oluşturdukları kompleks için farklılaştığını göstermektedir. Bu sonuçlara ek olarak, RMSF ve temel bileşen analizleri polimorfik rezidü olan D90A'nın AIFQSSMTK peptitini bağlayan HLA-A*03:01 alelinin stabilitesini artırmada oldukça önemli rol oynayabileceğini ortaya koymaktadır (Şekil 5 ve Şekil 8). Dahas1, AIFQSSMTK peptitini bağlayan HLA-A*03:01 alelinin T73 rezidüsü peptitin 6 . rezidüsü ile hidrojen bağı oluşturması [39] RMSF ve temel bileşenler analizleri de birlikte incelendiğinde, 73. rezidünün AIFQSSMTK peptitini bağlayan HLA-A*03:01 alelinin stabilitesini artırmasına sebep olabilmektedir (Şekil 5 ve Şekil 8).

Moleküler dinamik simülasyonundan elde edilen verilere ek olarak, ENCOM sunucusundan elde edilen HLA bağlanma motiflerinin doğruluğunun, deneysel verilerden elde edilen HLA bağlanma motifleriyle desteklendiği gözlemlenmiştir (Şekil 9). Bu bulgu, bağlanma tercih motifleri ile protein termostabilitesi arasında belirgin bir korelasyonun varlığına işaret etmektedir. ENCOM sunucusu kullanılarak yapılan normal mod analizleri, her iki peptitin de karboksi ucunda yapılan mutasyonların birincil derecede protein termostabilitesine negatif etki ettiğini ortaya çıkarmıştır. Fakat, QVPLRPMTYK peptidinin karboksi ucunda yapılan mutasyonların, AIFQSSMTK peptidinin aynı pozisyonunda yapılan mutasyonlara göre protein termostabilitesine daha negatif bir etkisinin olduğu gözlemlenmiştir. Ayrıca, AIFQSSMTK peptidinin 2. ve 3. rezidülerinde yapılan mutasyonların, QVPLRPMTYK peptidinin aynı pozisyonlarında yapılan mutasyonlara göre protein termostabilitesini daha negatif yönde etkilediği gözlemlenmiştir. Bu sonuçlara göre, QVPLRPMTYK peptiti için peptit bağlanmasında biricil derecede önemli olan 2. pozisyondaki rezidünün ve karboksi ucunda bulunan rezidünün protein termostabilitesine eşit derecede etkisinin olmadığı söylenebilir. Bu çalışma ayrıca, AIFQSSMTK peptidinin bağlanmasında ikincil derecede önemli olan 6. rezidüsünün ve QVPLRPMTYK peptitinin bağlanmasında ikincil derecede önemli olan 7. rezidüsünün [41] protein termostabilitesi için önemini açıkça ortaya çıkarmıştır. Çalışma kapsamında insan bağışıklik yetmezlik virüsü (HIV) epitopları olan AIFQSSMTK ve QVPLRPMTYK peptitlerini bağlayan HLA-A*03:01 ve HLA-A*11:01 alel komplekslerinin stabilitesi detayl bir şekilde araştırıldığı için, çalışma kapsamında elde edilen veriler sadece hesaplamalı yöntemlerle çalışan araştırmacılara değil, aynı zamanda deneysel çalışmalar yapan 
araştırmacılara da peptit immünojnite mekanizmasının anlaŞılabilmesi ve peptit bazlı aşıların geliştirilebilmesi için önfikir verebilecektir. Ayrıca, hesaplamalı yöntemlerin yaygın şekilde kullanılmasıyla, bu alanlarda yapılan deneysel araştırmaların sayısı, maliyeti ve süresi azaltılabilecektir.

\section{TEŞEKKÜR}

Bu çalışma TÜBİTAK 113M293 no'lu projenin sağladığ destek ile tamamlanmış olup, TÜBİTAK'a desteğinden dolayı teşekkür ederiz.

\section{KAYNAKLAR}

[1] Abbas, A. K., Lichtman, A. H., \& Pillai, S. (2015) Cellular and molecular immunology.

[2] Lafuente, E. M., ve Reche, P. A. (2009). Prediction of MHC-peptide binding: a systematic and comprehensive overview. Current Pharmaceutical Design, 15(28), 3209-20.

[3] Garrett, T. P. J., Saper, M. A., Bjorkman, P. J., Strominger, J. L., ve Wiley, D. C. (1989). Specificity pockets for the side chains of peptide antigens in HLA-Aw68 Nature, 342(6250), 692-696.

[4] Mamitsuka, H. (1998). Predicting peptides that bind to MHC molecules using supervised learning of hidden Markov models. Proteins, 33(4), 460-74. Retrieved from http://www. ncbi.nlm.nih.gov/pubmed/9849933

[5] Binkowski, T. A., Marino, S. R., ve Joachimiak, A. (2012). Predicting HLA Class I Non-Permissive Amino Acid Residues Substitutions PLoS ONE, 7(8), e41710.

[6] Sette, A., Buus, S., Appella, E., Smith, J. A., Chesnut, R., Miles, C., ve Grey, H. M. (1989). Prediction of major histocompatibility complex binding regions of protein antigens by sequence pattern analysis. Proceedings of the National Academy of Sciences of the United States of America, 86(9), 3296-300.

[7] Falk, K., Rötzschke, O., Stevanovié, S., Jung, G., ve Rammensee, H.-G. (1991). Allele-specific motifs revealed by sequencing of self-peptides eluted from MHC molecules $\mathrm{Na}$ ture, 351(6324), 290-296.

[8] Rammensee, H., Bachmann, J., Emmerich, N. P., Bachor, O. A., ve Stevanović, S. (1999). SYFPEITHI: database for MHC ligands and peptide motifs. Immunogenetics, 50(3-4), 213-9.

[9] Zhang, G. L., Khan, A. M., Srinivasan, K. N., August, J. T., ve Brusic, V. (2005). MULTIPRED: a computational system for prediction of promiscuous HLA binding peptides Nucleic Acids Research, 33(Web Server), W172-W179.

[10] Zhang, G. L., Bozic, I., Kwoh, C. K., August, J. T., ve Brusic, V. (2007). Prediction of supertype-specific HLA class I binding peptides using support vector machines Journal of Immunological Methods, 320(1-2), 143-154.
[11] Lin, H., Ray, S., Tongchusak, S., Reinherz, E. L., ve Brusic, V. (2008). Evaluation of MHC class I peptide binding prediction servers: Applications for vaccine research BMC Immunology, 9(1), 8.

[12] Rognan, D., Lauemoller, S. L., Holm, A., Buus, S., ve Tschinke, V. (1999). Predicting binding affinities of protein ligands from three-dimensional models: application to peptide binding to class I major histocompatibility proteins. Journal of Medicinal Chemistry, 42(22), 4650-8.

[13] Tong, J. C., Tan, T. W., ve Ranganathan, S. (2004). Modeling the structure of bound peptide ligands to major histocompatibility complex. Protein Science : A Publication of the Protein Society, 13(9), 2523-32.

[14] Kumar, N., ve Mohanty, D. (2007). MODPROPEP: a program for knowledge-based modeling of protein-peptide complexes Nucleic Acids Research, 35(Web Server), W549-W555.

[15] Serçinoğlu, O., Özcan, G., Kabaş, Z. K., ve Ozbek, P. (2016). A computational docking study on the $\mathrm{pH}$ dependence of peptide binding to HLA-B27 sub-types differentially associated with ankylosing spondylitis Journal of Computer-Aided Molecular Design, 30(7), 569-581.

[16] Jojic, N., Reyes-Gomez, M., Heckerman, D., Kadie, C., ve Schueler-Furman, O. (2006p). Learning MHC I--peptide binding Bioinformatics, 22(14), e227-e235.

[17] Sette, A., Vitiello, A., Reherman, B., Fowler, P., Nayersina, R., Kast, W. M., ... Chisari, F. V (1994). The relationship between class I binding affinity and immunogenicity of potential cytotoxic T cell epitopes. Journal of Immunology (Baltimore, Md. : 1950), 153(12), 5586-92.

[18] Ressing, M. E., Sette, A., Brandt, R. M., Ruppert, J., Wentworth, P. A., Hartman, M., Oseroff, C., Grey, H.M., Melief, C. J., Kast, W. M. (1995). Human CTL epitopes encoded by human papillomavirus type 16 E6 and E7 identified through in vivo and in vitro immunogenicity studies of HLAA*0201-binding peptides. Journal of Immunology (Baltimore, Md. : 1950), 154(11), 5934-43.

[19] Harndahl, M., Rasmussen, M., Roder, G., Dalgaard Pedersen, I., Sørensen, M., Nielsen, M., ve Buus, S. (2012). Peptide-MHC class I stability is a better predictor than peptide affinity of CTL immunogenicity European Journal of Immunology, 42(6), 1405-1416.

[20] Lim, J. S., Kim, S., Lee, H. G., Lee, K. Y., Kwon, T. J., ve Kim, K. (1996). Selection of peptides that bind to the HLA-A2.1 molecule by molecular modelling. Molecular Immunology, 33(2), 221-30.

[21] Nielsen, M. (2007) NetMHCpan, a method for quantitative predictions of peptide binding to any HLA-A and - B locus protein of known sequence PLoS One, 2(8), 796.

[22] Jørgensen, K. W., Rasmussen, M., Buus, S., and Nielsen, M. (2014). NetMHCstab - predicting stability of peptide-MHC-I complexes; impacts for cytotoxic T lymphocyte epitope discovery Immunology, 141(1), 18-26. 
[23] Rasmussen, M. (2016). Pan-Specific Prediction of Peptide-MHC Class I Complex Stability, a Correlate of T Cell Immunogenicity J. Immunol., 197(4), 1517-24.

[24] Dedier, S. (2000). Thermodynamic Stability of HLA-B*2705/ Peptide Complexes: Effect of Peptide and MHC Protein mutations Journal of Biological Chemistry, 275(35), 2705527061.

[25] Ozbek, P. (2016). Dynamic characterization of HLA-B*44 Alleles: A comparative molecular dynamics simulation study Computational Biology and Chemistry, 62, 12-16.

[26] Serçinoğlu, O., ve Ozbek, P. (2018). Computational characterization of residue couplings and micropolymorphism-induced changes in the dynamics of two differentially disease-associated human MHC class-I alleles Journal of Biomolecular Structure and Dynamics, 36(3), 724-740.

[27] Fabian, H. (2008) HLA-B27 Subtypes Differentially Associated with Disease Exhibit Conformational Differences in Solution J. Mol. Biol., 376(3), 798-810.

[28] Narzi, D., Becker, C. M., Fiorillo, M. T., Uchanska-Ziegler, B., Ziegler, A., ve Böckmann, R. A. (2012) Dynamical Characterization of Two Differentially Disease Associated MHC Class I Proteins in Complex with Viral and Self-Peptides $J$. Mol. Biol., 415(2), 429-442.

[29] Abualrous E. T. (2015) F pocket flexibility influences the tapasin dependence of two differentially disease-associated MHC Class I proteins Eur. J. Immunol., 45(4), 1248-1257.

[30] Binz, A.-K., Rodriguez, R. C., Biddison, W. E., ve Baker, B. M. (2003). Thermodynamic and Kinetic Analysis of a Peptide-Class I MHC Interaction Highlights the Noncovalent Nature and Conformational Dynamics of the Class I Heterotrimer $^{\dagger}$ Biochemistry, 42(17), 4954-4961.

[31] Zacharias, M., ve Springer, S. (2004). Conformational flexibility of the MHC class I alpha1-alpha2 domain in peptide bound and free states: a molecular dynamics simulation study. Biophysical Journal, 87(4), 2203-14.

[32] Camacho, C. J., Katsumata, Y., ve Ascherman, D. P. (2008). Structural and Thermodynamic Approach to Peptide Immunogenicity PLoS Computational Biology, 4(11), e1000231.

[33] Lonquety, M., Lacroix, Z., Papandreou, N., ve Chomilier, J. (2009). SPROUTS: a database for the evaluation of protein stability upon point mutation Nucleic Acids Research, 37(suppl_1), D374-D379.

[34] Razvi, A., ve Scholtz, J. M. (2006). Lessons in stability from thermophilic proteins Protein Science, 15(7), 1569-1578.

[35] Frappier, V., ve Najmanovich, R. (2015). Vibrational entropy differences between mesophile and thermophile proteins and their use in protein engineering Protein Science, 24(4), 474-483.
[36] Sidney, J., Grey, H. M., Southwood, S., Celis, E., Wentworth, P. A., del Guercio, M. F., ... Sette, A. (1996). Definition of an HLA-A3-like supermotif demonstrates the overlapping peptide-binding repertoires of common HLA molecules. Human Immunology, 45(2), 79-93.

[37] Racape, J., Connan, F., Hoebeke, J., Choppin, J., ve Guillet, J.-G. (2006). Influence of dominant HIV-1 epitopes on HLA-A3/peptide complex formation. Proceedings of the $\mathrm{Na}$ tional Academy of Sciences of the United States of America, 103(48), 18208-18213.

[38] Lichterfeld, M., Williams, K. L., Mui, S. K., Shah, S. S., Mothe, B. R., Sette, A., ... Yu, X. G. (2006). T cell receptor cross-recognition of an HIV-1 CD8+ T cell epitope presented by closely related alleles from the HLA-A3 superfamily. International Immunology, 18(7), 1179-1188.

[39] Zhang, S., Liu, J., Cheng, H., Tan, S., Qi, J., Yan, J., ve Gao, G. F. (2011). Structural basis of cross-allele presentation by HLA-A*0301 and HLA-A*1101 revealed by two HIV-derived peptide complexes Molecular Immunology, 49(1-2), 395-401.

[40] Berman, H. M., Westbrook, J., Feng, Z., Gilliland, G., Bhat, T. N., Weissig, H., Shindyalov, ve Bourne, P. E. (2000). The Protein Data Bank. Nucleic Acids Research, 28(1), 235-42.

[41] Li, L., ve Bouvier, M. (2004). Structures of HLA-A*1101 complexed with immunodominant nonamer and decamer HIV-1 epitopes clearly reveal the presence of a middle, secondary anchor residue. Journal of Immunology (Baltimore, Md. : 1950), 172(10), 6175-6184.

[42] Phillips, J. C., Braun, R., Wang, W., Gumbart, J., Tajkhorshid, E., Villa, E., Chipot., C., Skeel, R. D., Kale ve Schulten, K. (2005). Scalable molecular dynamics with NAMD Journal of Computational Chemistry, 26(16), 1781-1802.

[43] Brooks, B. R., Bruccoleri, R. E., Olafson, B. D., States, D. J., Swaminathan, S., ve Karplus, M. (1983). CHARMM: A program for macromolecular energy, minimization, and dynamics calculations Journal of Computational Chemistry, 4(2), 187-217.

[44] Eswar, N., Webb, B., Marti-Renom, M. A., Madhusudhan, M. S., Eramian, D., Shen, M., Pieper U., ve Sali, A. (2006). Comparative Protein Structure Modeling Using Modeller In Current Protocols in Bioinformatics (Vol. Chapter 5, p. 5.6.15.6.30).

[45] Frappier, V., Chartier, M., ve Najmanovich, R. J. (2015). ENCoM server: exploring protein conformational space and the effect of mutations on protein function and stability Nucleic Acids Research, 43(W1), W395-W400. 